\title{
PENGARUH PENGUASAAN KOSAKATA DAN TATA BAHASA TERHADAP KEMAMPUAN MENULIS TEKS RECOUNT BAHASA INGGRIS
}

\author{
Yuni Istiqomah $^{1}$ \\ Hasbullah $^{2}$ \\ Postgraduate Faculty, English Language Program \\ Universitas Indraprasta PGRI, Jakarta \\ e-mail: yuniistiqomah1@gmail.com ${ }^{1}$ \\ email: hasbullah@unindra.ac.id ${ }^{2}$
}

\begin{abstract}
This study aims to determine: The effect of vocabulary and grammar mastery on the English recount text writing skills of state junior high. The results of the hypothesis obtained the following conclusions: (1) There is a significant influence in mastering the vocabulary and grammar together on the ability to write English recount text in junior high school. This is shown from the value of Sig $0.010<0.05$ and $F_{h}=4.972$. (2) There is a significant influence of vocabulary mastery on writing English recount text of state junior high school. This is shown from the value of Sig 0.033 $<0.05$ and $t_{h}=2192$. (3) There is a significant influence of grammar mastery on writing English recount text of state junior high school. This is shown from the value of Sig $0.039<0.05$ and $t_{h}=$ 2.111 .
\end{abstract}

Keywords: vocabulary, grammar, recount text

\section{Pendahuluan}

Dari waktu ke waktu bahasa merupakan alat komunikasi untuk menyampaikan atau mengemukakan berbagai hal baik lisan maupun tulisan. Dalam kehidupan sehari-hari bahasa digunakan untuk menyampaikan dan menyelesaikan berbagai keperluan termasuk penyelenggaraan pendidikan. Salah satu bahasa yang paling sering di gunakan di seluruh dunia yaitu bahasa Inggris, maka bahasa Inggris disebut juga dengan bahasa dunia atau bahasa internasional. Bahasa Inggris juga sering di gunakan sebagai bahasa pengantar dalam berbagai acara yang bersifat internasional. Bahasa Inggris sebagai bahasa internasional yang dipelajari dalam berbagai negara didunia ini termasuk di Indonesia. Sebagai bahasa internasional, bahasa Inggris merupakan peranan penting dalam berbagai hal, seperti dunia usaha, pendidikan, serta pergaulan dengan berbagai bangsa. Hal ini terlihat pada berbagai media informasi sebagian besar sumber informasi yang sebagian besar sumber informasi ditulis dalam bahasa Inggris. Oleh karena itu, seseorang yang kemampuan bahasa Inggrisnya baik akan lebih mudah meningkatkan pengetahuan dan keterampilan. Vygostsky (1978) Mengemukakan bahwa bahasa adalah alat untuk mencapai dan menyelesaikan berbagai masalah dalam kehidupan nyata.

Bahasa dipandang sebagai alat yang efektif untuk menciptakan manusia yang tangguh dan kompetitif. Karenanya, bahasa Inggris adalah bahasa internasional, maka pembelajaran bahasa Inggris disekolah harus mampu membekali siswanya untuk menguasai keterampilan berbahasa inggris baik bersifat keterampilan memproduksi seperti menulis dan berbicara. Dilain pihak para siswa seyogyanya memiliki keinginan kuat untuk menguasai bahasa Inggris. Bahasa Inggris juga mempunyai peran penting dalam pendidikan dan menjadi salah satu mata pelajaran yang penting baik dari pendidikan dasar sampai ke pendidikan yang lebih tinggi. Mengingat pentingnya mempelajari bahasa Inggris dalam pendidikan, maka pemerintah menjadikan bahasa inggris menjadi salah satu kurikulum yang terdapat di setiap sekolah. Dari sekolah dasar sampai perguruan tinggi, bahasa Inggris menjadi salah satu pelajaran yang harus dipelajari. Meskipun bahasa Inggris sudah diperkenalkan sejak dini, tetapi banyak dari mereka yang masih merasa kesulitan. Seperti sulit untuk mengingat kosakata, memahami percakapan dan membuat kalimat-kalimat dalam bahasa Inggris. Dalam 


\section{INFERENCE: Journal of English Language Teaching}

Vol. 4, No. 3, December 2021 - March 2022

p-ISSN: 2615-8671

e-ISSN: 2615-868X

pendidikan formal maupun informal, bahasa Inggris memiliki empat keahlian yaitu Mendengarkan (Listening), Berbicara (Speaking), Membaca (Reading) dan Menulis (Writing). Menulis (Writing) adalah salah satu keterampilan yang harus dikuasai oleh peserta didik untuk membuat huruf, kata, frasa, kalimat dan teks. Tetapi, dalam menulis sebuah teks, tidak jarang peserta didik mengalami kesalahan dalam menulis sebuah teks didalam bahasa inggris, seperti perbendaharaan kata, penggunaan tata bahasa, dan lain-lain. Salah satu kesalahan yang sering terjadi pada peserta didik dalam menulis sebuah teks adalah penggunaan tata bahasa. Padahal, penggunaan tata bahasa berperan sangat penting dalam membuat menulis teks. Di dalam bahasa Inggris, ada beberapa teks seperti naratif, recount, deskriptif, laporan, dan prosedur. Dalam penelitian ini, penulis hanya mengambil satu teks saja yang akan diteliti, yaitu teks recount. Teks recount merupakan salah satu jenis teks bahasa inggris yang bisa dikatakan sebagai teks sederhana karena memaparkan sesuatu yang sudah lazim dari hal-hal atau kejadian sehari-hari. Teks recount adalah jenis teks yang melaporkan peristiwa, kejadian, atau kegiatan yang menimpa seseorang atau berupa pengalaman seseorang. Dan teks recount menggunakan tata bahasa simple past tense, yaitu penggunaan kata kerja bentuk lampau (v2). Sehingga penulis memfokuskan penggunaan tata bahasa pada simple past tense. Kesalahan peserta didik dalam penggunaan tata bahasa yaitu simple past tense sering terjadi, terutama mereka salah menulis kata kerja. Atas dasar itulah penulis merasa tertarik untuk mengadakan penelitian tentang "pengaruh penguasaan kosakata dan tata bahasa terhadap kemampuan menulis teks recount bahasa inggris siswa SMP Negeri di Jakarta Timur".

\section{Metode}

Penelitian dilakukan dilingkungan SMP Negeri di Jakarta Timur. Objek penelitian diambil dari siswa kelas VIII Tahun Pelajaran 2019/2020, terdiri dari 2 (dua) sekolah. Metode penelitian yang di gunakan adalah metode survey. Jenis penelitiannya adalah deskriptif korelasional yang berupaya menyatakan ada tidaknya pengaruh penguasaan kosakata dan tata bahasa sebagai variable bebas terhadap kemampuan menulis teks recount sebagai variable terikat pada siswa SMP Negeri kelas VIII di Jakarta Timur.

\section{Hasil dan Diskusi}

Deskripsi data: Data Kemampuan Menulis Teks Recount (Y) diperoleh skor terendah 55 dan skor tertinggi 90, rata-rata sebesar (mean) 67.08, median sebesar 66, modus sebesar 55 dan simpangan baku (Std. Deviation) 8,35. Dari data di atas dapat dikatakan bahwa kemampuan menulis teks recount bahasa Inggris SMP Negeri di Jakarta Timur tergolong baik. Hal ini diindikasikan dengan perolehan nilai rata-rata (mean) sebesar 67,08. Untuk memperjelas data, dapat dilihat dari tabel hasil perhitungan dan histogram sebagai berikut:

Tabel 1. Perhitugan Nilai Rata-rata Statistics

Kemampuan Menulis Teks Recount (Y)

\begin{tabular}{|c|c|c|}
\hline \multirow{2}{*}{$\mathrm{N}$} & Valid & 60 \\
\hline & Missing & 0 \\
\hline & Mean & 67.08 \\
\hline & Median & 66.00 \\
\hline & Mode & $55^{\mathrm{a}}$ \\
\hline & Std. Deviation & 8.357 \\
\hline & Minimum & 55 \\
\hline & Maximum & 90 \\
\hline
\end{tabular}

a. Multiple modes exist. The smallest value is shown 


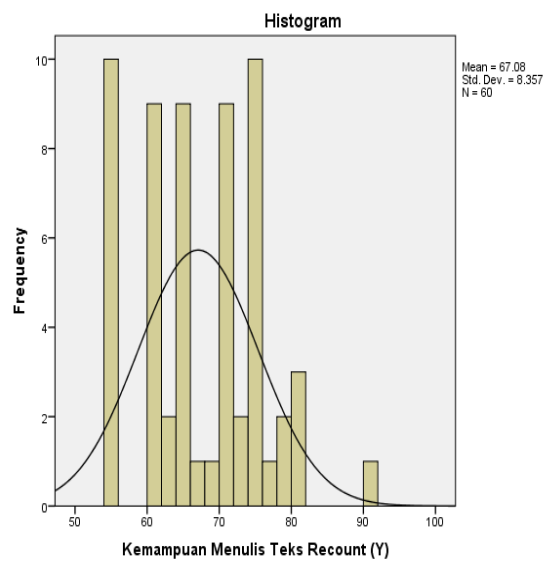

Diagram 1. Histogram Deskripsi Data

Data Penguasaan Kosakata $\left(\mathrm{X}_{1}\right)$ diperoleh skor terendah 12 dan skor tertinggi 80, rata-rata sebesar (mean) 52,33, median sebesar 52, modus sebesar 60 dan simpangan baku (Std. Deviation) 14,21. Dari data di atas dapat dikatakan bahwa penguasaan kosakata SMP Negeri di Jakarta Timur tergolong baik. Hal ini diindikasikan dengan perolehan nilai rata-rata (mean) sebesar 52,33. Untuk memperjelas data, dapat dilihat dari tabel hasil perhitungan dan histogram sebagai berikut:

Tabel 2. Perhitungan Data Penguasaan Kosakata Statistics

\begin{tabular}{|cc|c|}
\hline \multicolumn{2}{|c|}{ Penguasaan Kosakata (X1) } \\
\hline \multirow{2}{*}{$\mathrm{N}$} & Valid & 60 \\
\cline { 2 - 3 } & Missing & 0 \\
\hline Mean & 52.33 \\
\hline Median & 52.00 \\
\hline Mode & 60 \\
\hline Std. Deviation & 14.210 \\
\hline Minimum & 12 \\
\hline Maximum & 80 \\
\hline
\end{tabular}

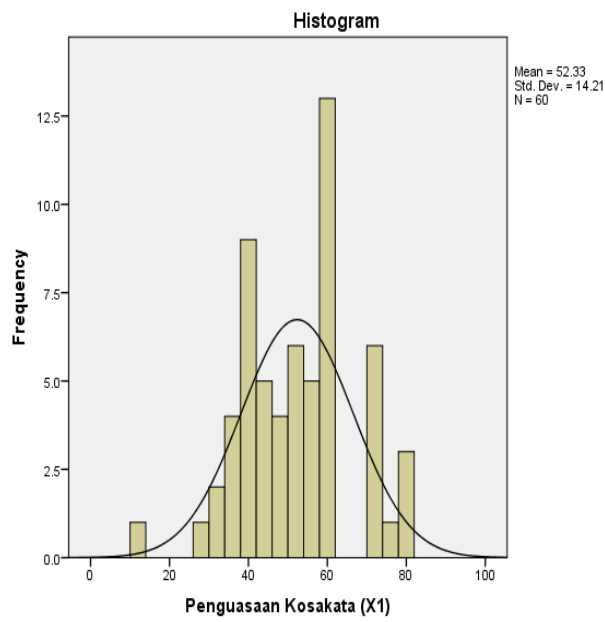

Diagram 2. Penguasaan Kosakata

Data Penguasaan Tata Bahasa $\left(\mathrm{X}_{2}\right)$ diperoleh skor terendah 28 dan skor tertinggi 68, rata-rata sebesar (mean) 48,87, median sebesar 52, modus sebesar 60 dan simpangan baku (Std. Deviation) 11,72. Dari data di 
INFERENCE: Journal of English Language Teaching

Vol. 4, No. 3, December 2021 - March 2022

p-ISSN: 2615-8671

e-ISSN: 2615-868X

atas dapat dikatakan bahwa penguasaan tata bahasa SMP Negeri di Jakarta Timur tergolong baik. Hal ini diindikasikan dengan perolehan nilai rata-rata (mean) sebesar 48,87 . Untuk memperjelas data, dapat dilihat dari tabel hasil perhitungan dan histogram sebagai berikut:

Tabel 3. Penguasaan Tata Bahasa Statistics

Penguasaan Tata Bahasa (X2)

\begin{tabular}{|c|c|}
\hline \multirow{2}{*}{$\mathrm{N}$ Valid } & 60 \\
\cline { 2 - 3 } Missing & 0 \\
\hline Mean & 48.87 \\
\hline Median & 52.00 \\
\hline Mode & 60 \\
\hline Std. Deviation & 11.722 \\
\hline Minimum & 28 \\
\hline Maximum & 68 \\
\hline
\end{tabular}

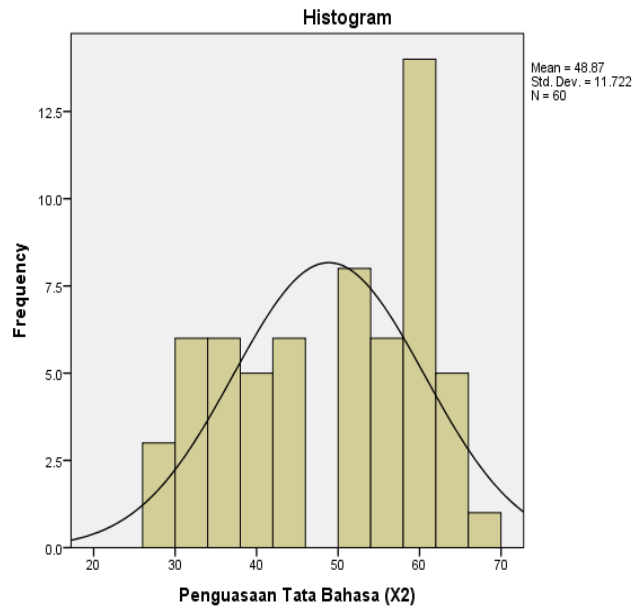

Diagram 3. Histogram Penguasaan Tata Bahasa

Tabel 4. Uji Persyarata Analisis Regresi

\begin{tabular}{|c|c|c|c|}
\hline \multicolumn{4}{|c|}{ Coefficients $^{\mathrm{a}}$} \\
\hline & \multirow[t]{2}{*}{ Model } & \multicolumn{2}{|c|}{ Collinearity Statistic } \\
\hline & & Tolerance & VIF \\
\hline \multicolumn{4}{|c|}{ (Constant) } \\
\hline \multirow{2}{*}{1} & Penguasaan Kosakata (X1) & .995 & 1.005 \\
\hline & Penguasaan Tata Bahasa (X2) & .995 & 1.005 \\
\hline
\end{tabular}

a. Dependent Variable: Kemampuan Menulis Teks Recount (Y)

Tabel 5. Uji Normalitas Data

One-Sample Kolmogorov-Smirnov Test

\begin{tabular}{|c|c|c|c|c|}
\hline & & $\begin{array}{c}\text { Penguasaan } \\
\text { Kosakata (X1) }\end{array}$ & $\begin{array}{c}\text { Penguasaan Tata } \\
\text { Bahasa (X2) }\end{array}$ & $\begin{array}{l}\text { Kemampuan } \\
\text { Menulis Teks } \\
\text { Recount (Y) }\end{array}$ \\
\hline \multicolumn{2}{|c|}{$\mathrm{N}$} & 60 & 60 & 60 \\
\hline \multirow{3}{*}{ Normal Parameters ${ }^{\mathrm{a}, \mathrm{b}}$} & Mean & 52.33 & 48.87 & 67.08 \\
\hline & Std. Deviation & 14.210 & 11.722 & 8.357 \\
\hline & Absolute & .128 & .162 & .118 \\
\hline \multirow[t]{2}{*}{ Most Extreme Differences } & Positive & .128 & .114 & .118 \\
\hline & Negative & -.089 & -.162 & -.112 \\
\hline \multicolumn{2}{|c|}{ Kolmogorov-Smirnov Z } & .992 & 1.257 & .917 \\
\hline \multicolumn{2}{|c|}{ Asymp. Sig. (2-tailed) } & .278 & .085 & .370 \\
\hline
\end{tabular}


a. Test distribution is Normal.

b. Calculated from data.

Tabel di atas menunjukkan bahwa uji hipotesis terhadap distribusi data pada analisis regresi ini mengikuti distribusi normal. Hal ini ditunjukkan dengan nilai Asymp. Sig. > 0,05. Hal ini berarti semua data berdistribusi normal.

\section{Uji Multikolinearitas}

Dari table diatas dapat diketahui bahwa hasil uji multikolinearitas menunjukkan hasil Tolerance $0,995>0,1$ atau Varian Inflation Factor (VIF) $1,005<10$. Sehingga dapat dinyatakan bahwa tidak ada multikolinearitas antara penguasaan kosakta dengan penguasaan tata bahasa pada analisis regresi ganda.

\section{Uji Heteroskedastisitas}

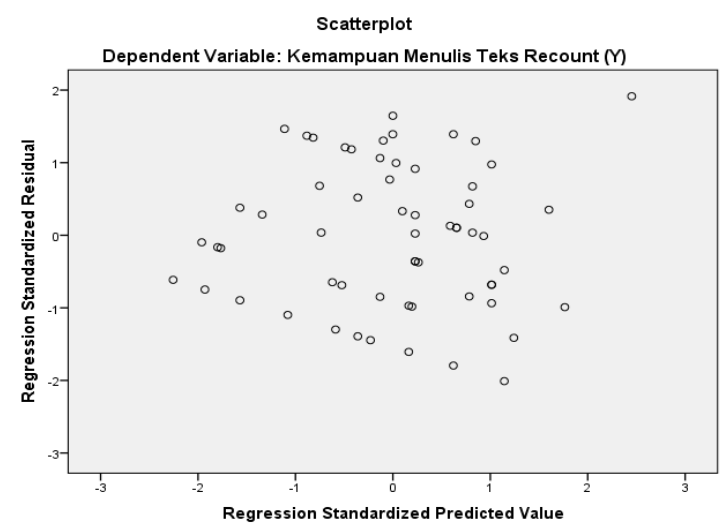

Gambar 4. Scatterplot antara Variabel Terikat dan Tidak Terikat

Gambar di atas menunjukkan bahwa titik-titik menyebar secara acak dari tidak membentuk pola tertentu yang jelas, serta tersebar di atas maupun di bawah angka 0 pada sumbu Y. Hal ini menunjukkan bahwa tidak terjadi heteroskedastisitas pada model regresi tersebut, sehingga dapat dipakai untuk memprediksi variable kemampuan menulis teks recount Bahasa Inggris berdasarkan penguasaan kosakata dan penguasaan tata bahasa.

3. Uji Normalitas Galat

Tabel 6. Hasil Uji Normalitas Galat One-Sample Kolmogorov-Smirnov Test

\begin{tabular}{|c|c|c|}
\hline \multicolumn{2}{|c|}{} & $\begin{array}{c}\text { Unstandardized } \\
\text { Residual }\end{array}$ \\
\hline \multirow{2}{*}{$\mathrm{N}$} & 60 \\
\hline \multirow{2}{*}{ Normal Parameters ${ }^{\mathrm{a}, \mathrm{b}}$} & Mean & .0000000 \\
\cline { 2 - 3 } Most Extreme Differences & Std. Deviation & 7.71142759 \\
\cline { 2 - 3 } & Absolute & .084 \\
\cline { 2 - 3 } & Positive & .084 \\
\hline \multicolumn{2}{|c|}{ Negative } & -.074 \\
\hline Kolmogorov-Smirnov Z & .650 \\
\hline \multicolumn{2}{|c|}{ Asymp. Sig. (2-tailed) } \\
\hline
\end{tabular}

a. Test distribution is Normal.

b. Calculated from data.

Tabel di atas menunjukkan bahwa uji hipotesis menyatakan distribusi residual pada analisis regresi ini mengikuti distribusi normal. Hal ini ditunjukkan dengan nilai $\mathrm{Z}=650$ dan Sig. $=0,792$. Hal ini berarti bahwa asumsi atau persyaratan analisis regresi terpenuhi. 
INFERENCE: Journal of English Language Teaching

Vol. 4, No. 3, December 2021 - March 2022

p-ISSN: 2615-8671

e-ISSN: 2615-868X

5. Uji Linieritas

a. Liniearitas Regresi Pengaruh Variabel $\mathrm{Y}$ atas $\mathrm{X}_{1}$

Tabel 7. Linearitas Regresi

\begin{tabular}{|c|c|c|c|c|c|c|c|}
\hline \multicolumn{8}{|c|}{ ANOVA Table } \\
\hline & & & Sum of Squares & df & Mean Square & $\mathrm{F}$ & Sig. \\
\hline \multirow{5}{*}{$\begin{array}{c}\text { Kemampuan Menulis } \\
\text { Teks Recount (Y)* } \\
\text { Penguasaan Kosakata } \\
\text { (X1) }\end{array}$} & \multirow{3}{*}{$\begin{array}{l}\text { Between } \\
\text { Groups }\end{array}$} & (Combined) & 1544.371 & 12 & 128.698 & 2.348 & .019 \\
\hline & & Linearity & 337.888 & 1 & 337.888 & 6.164 & .017 \\
\hline & & $\begin{array}{l}\text { Deviation from } \\
\text { Linearity }\end{array}$ & 1206.483 & 11 & 109.680 & 2.001 & .050 \\
\hline & \multicolumn{2}{|c|}{ Within Groups } & 2576.212 & 47 & 54.813 & & \\
\hline & \multicolumn{2}{|c|}{ Total } & 4120.583 & 59 & & & \\
\hline
\end{tabular}

Berdasarkan hasil perhitungan di atas diperoleh hasil perhitungan Deviation from Linearity dengan $\mathrm{Fo}=2,001$ dan Sig. 0,050>0,05. Hal ini memiliki pegertian bahwa variable penguasaan kosakata dengan kemampuan menulis teks recount mempunyai hubungan yang linier.

b. Linearitas Regresi Pengaruh Variabel $\mathrm{Y}$ atas $\mathrm{X}_{2}$

Tabel 8. Linearitas Regresi Variabel $\mathrm{Y}$ atas $\mathrm{X}_{2}$

ANOVA Table

\begin{tabular}{|c|c|c|c|c|c|c|c|}
\hline & & & Sum of Squares & df & Mean Square & $\mathrm{F}$ & Sig. \\
\hline \multirow{5}{*}{$\begin{array}{c}\text { Kemampuan } \\
\text { Menulis Teks } \\
\text { Recount (Y)* } \\
\text { Penguasaan Tata } \\
\text { Bahasa (X2) }\end{array}$} & \multirow{3}{*}{ Between Groups } & (Combined) & 1015.024 & 11 & 92.275 & 1.426 & .192 \\
\hline & & Linearity & 316.437 & 1 & 316.437 & 4.891 & .032 \\
\hline & & Deviation from Linearity & 698.587 & 10 & 69.859 & 1.080 & .396 \\
\hline & \multicolumn{2}{|c|}{ Within Groups } & 3105.560 & 48 & 64.699 & & \\
\hline & \multicolumn{2}{|r|}{ Total } & 4120.583 & 59 & & & \\
\hline
\end{tabular}

Berdasarkan hasil perhitungan di atas di peroleh hasil perhitungan Deviation from Linearity dengan Fo $=1,080$ dan Sig. $=0,396>0,05$. Hal ini memiliki pengertian bahwa variable penguasaan tata bahasa dan kemampuan menulis teks recount mempunyai hubungan yang linear.

\section{Uji Hipotesis}

Tabel 9. Hasil Perhitungan Pengujian Koefisien Korelasi Ganda Variabel $\mathrm{X}_{1}$ dan $\mathrm{X}_{2}$ terhadap Y

Model Summary

\begin{tabular}{|c|c|c|c|c|}
\hline Model & $\mathrm{R}$ & $\mathrm{R}$ Square & Adjusted R Square & $\begin{array}{c}\text { Std. Error of the } \\
\text { Estimate }\end{array}$ \\
\hline 1 & $.385^{\mathrm{a}}$ & .149 & .119 & 7.846 \\
\hline
\end{tabular}

a. Predictors: (Constant), Penguasaan Tata Bahasa (X2), Penguasaan Kosakata (X1)

b. Dependent Variable: Kemampuan Menulis Teks Recount (Y)

Tabel 10. Hasil Perhitungan Pengujian Koefisien Korelasi Regresi Variabel $X_{1}$ dan $X_{2}$ terhadap $Y$ ANOVA $^{\mathrm{a}}$

\begin{tabular}{|c|c|c|c|c|c|c|}
\hline & Model & Sum of Squares & df & Mean Square & $\mathrm{F}$ & Sig. \\
\hline \multirow{3}{*}{1} & Regression & 612.083 & 2 & 306.041 & 4.972 & $.010^{\mathrm{b}}$ \\
\hline & Residual & 3508.501 & 57 & 61.553 & & \\
\hline & Total & 4120.583 & 59 & & & \\
\hline
\end{tabular}

a. Dependent Variable: Kemampuan Menulis Teks Recount (Y)

b. Predictors: (Constant), Penguasaan Tata Bahasa (X2), Penguasaan Kosakata (X1)

Tabel 11. Hasil Perhitungan Persamaan Regresi Ganda Variabel $X_{1}$ dan $X_{2}$ terhadap $Y$ 


\begin{tabular}{|c|c|c|c|c|c|c|}
\hline Coefficients $^{\mathrm{a}}$ & & & & & & \\
\hline & \multirow[t]{2}{*}{ Model } & \multicolumn{2}{|c|}{ Unstandardized Coefficients } & \multirow{2}{*}{$\begin{array}{c}\text { Standardized } \\
\text { Coefficients } \\
\text { Beta }\end{array}$} & \multirow[t]{2}{*}{$\mathrm{T}$} & \multirow[t]{2}{*}{ Sig. } \\
\hline & & $\mathrm{B}$ & Std. Error & & & \\
\hline \multirow{3}{*}{1} & (Constant) & 49.811 & 5.589 & & 8.912 & .000 \\
\hline & Penguasaan Kosakata (X1) & .158 & .072 & .268 & 2.192 & .033 \\
\hline & Penguasaan Tata Bahasa (X2) & .184 & .087 & .259 & 2.111 & .039 \\
\hline
\end{tabular}

a. Dependent Variable: Kemampuan Menulis Teks Recount (Y)

Dari tabel di atas dapat disimpulkan terdapat pengaruh yang signifikan penguasaan tata bahasa terhadap kemampuan menulis teks recount bahasa Inggris. Hal ini dibuktikan dengan perolehan data Sig. $0,039<0,05$ dan $\mathrm{t}_{\mathrm{h}}=2.11$.

1. Pengaruh Penguasaan Kosakata $\left(X_{1}\right)$ dan Pengaruh Penguasaan Tata Bahasa $\left(X_{2}\right)$ secara bersama-sama terhadap Kemampuan Menulis Teks Recount Bahasa Inggris (Y)

Dari hasil penelitian di atas dapat disimpulkan bahwa penguasaan kosakata dan tata bahasa secara bersamasama telah memberikan pengaruh yang signifikan terhadap kemampuan menulis teks recount Bahasa Inggris di SMP Negeri Jakarta Timur.

2. Pengaruh Penguasaan Kosakata $\left(\mathrm{X}_{1}\right)$ terhadap Kemampuan Menulis Teks Recount Bahasa Inggris (Y) Dari penelitian di atas, dapat dinyatakan bahwa penguasaan kosakata telah memberikan pengaruh yang signifikan terhadap kemampuan teks recount Bahasa Inggris SMP Negeri di Jakarta Timur.

3. Pengaruh Penguasaan Tata Bahasa $\left(\mathrm{X}_{2}\right)$ terhadap Kemampuan Menulis Teks Recount Bahasa Inggris (Y). Dari penelitian di atas disimpulkan bahwa antara penguasaan tata bahasa memberikan pengaruh yang signifikan terhadap kemampuan menulis teks recount bahasa Inggris SMP Negeri di Jakarta

\section{Simpulan}

Berdasarkan hasil analisis data dan pembahasan dapat disimpulkan sebagai berikut :

1. Terdapat pengaruh yang signifikan penguasaan kosakata dan tata bahasa secara bersama-sama terhadap kemampuan menulis teks recount Bahasa Inggris siswa SMP Negeri di Jakarta Timur dibuktikan dengan perolehan Sig. 0,010 $<0,05$ dan $F_{\text {hitung }}=4,972$.

2. Terdapat pengaruh yang signifikan penguasaan kosakata terhadap kemampuan menulis teks recount Bahasa Inggris siswa SMP Negeri di Jakarta Timur. Hal ini dibuktikan dengan perolehan Sig. 0,033 < 0,05 dan $\mathrm{t}_{\text {hitung }}=2.192$.

3. Terdapat pengaruh yang signifikan antara penguasaan tata bahasa terhadap kemampuan menulis teks recount Bahasa Inggris siswa SMP Negeri di Jakarta Timur. Hal ini dibuktikan dengan perolehan Sig. $0,039<0,05$ dan $\mathrm{t}_{\text {hitung }}=2.111$

\section{Daftar Rujukan}

Ahmadi, A (2004). Psikologi belajar. Jakarta: Rineka Cipta

Arikunto,S (2009). Prosedur penelitian, Jakarta: PT. Rineka Cipta.

Brown. 2003. Teaching with media, a paper presented at Technology and Education Conference in Athens, Greece.

Carol. (2007). Kreativitas dalam bisnis. Jakarta : Binarupa Aksara.

Bambang. (2006). Teaching Foreign Language. Jakarta: Universitas Terbuka.

Davies, Paul.(2002). Success in English Teaching. Oxford University Press: New York

Gay, R. (2003). Metode penelitian. Bandung : Rajawali.

Hasbullah. (2004). Media pembelajaran. Solo : Tiga Serangkai.

Keraf, G. (2004). Tata Bahasa Indonesia. Enda Flores: Nusa Indah.

Nasution, S. (2005). Didakti metodik. Bandung : Jenmars.

Nunan, D. (1992). Mengembangkan pemahaman wacana. Jakarta: PT. Rebia Indah Prakasa

Richard, J. C. (2001). Curriculum Development in Language Teaching. New York: Cambridge University Press.

Robbin, S. P. \& Timothy A. J., (2009). Perilaku Organisasi. Jakarta: Salemba Empat.

Sanjaya, W. (2009). Strategi pembelajaran: Berorientasi standar proses pendidikan. Jakarta: Prenada Media Group Kedua 
INFERENCE: Journal of English Language Teaching

Vol. 4, No. 3, December 2021 - March 2022

p-ISSN: 2615-8671

e-ISSN: 2615-868X

Santoso, S. (2001). Buku Latihan SPSS, Edisi Kedua. Jakarta: PT. Elex Media Komputindo.

Soekamto, T. (2008). Psikologi pendidikan : Suatu pendekatan praktis, Jakarta : Bina Aksara.

Sudjana, N. (2001). Dasar-dasar proses belajar mengajar. Bandung: Rosda Karya.

Sudjana. (2005). Metode Statistika. Bandung: Tarsito.

Sudirman, A. M. (2009). Metodologi Penelitian. Metro: FKIP UM Metro.

Sugiyono. (2016). Metode Penelitian Administrasi, Bandung.

Sugiyono. (2013). Metode Penelitian Pendidikan: Pendekatan Kuantitatif, Kualitatif dan R\&D. Bandung: Alphabeta Bandung.

Supardi, U.S. (2011). Aplikasi statistika dalam penelitian. Jakarta: Ufuk Press, Februari.

Suparman, S. (2010). Gaya belajar yang menyenangkan siswa. Yogyakarta: Pinus Book Publisher.

Thornburry, S. (2002). How to Teach Vocabulary. London: Pearson Educated Limited. 